\title{
Contribution of Indonesia to International and Regional Civil Aviation
}

\author{
Ms Mia Hadiati ${ }^{1}$ and Prof.Dr.Martono ${ }^{2}$
}

\begin{abstract}
This article deals with introduction; legal ground of Indonesian aviation activities; contribution of Indonesia to international and regional of civil aviation such as coordination with ICAO, civil aviation, public international air law regime including amendment of the Chicago Convention of 1944, ratification Tokyo Convention of 1963, The Hague Convention of 1970 and Montreal Convention of 1971; Ratification of Cape Town Convention of 2001 including the content, international interest in aircraft, its implementation, legal aspect, definition, applicability, the most important provision, the benefit of the CTC of 2001, the best practices uch as general indication, Garuda Indonesia, the successful of other airlines, obstacle of the implementation and conclusion; Montreal Agreement of 1999 including scope of application, compensation, advance payment, insurance, jurisdiction and ratification; contribution to the ASEAN countries such SAR, ASEAN Multilateral Agreement on Commercial of non-scheduled air services, AMAAS and the ASEAN Aviation Training and Education Summit and finally conclusion.
\end{abstract}

\section{Introduction}

The Republic of Indonesia (ROI) is a large archipelagic country with more than 17,000 Islands and airspace spanning 5,500 km from East to West and 2,430 km from North to South, covering of the earth's equator, for that reason air transport links are therefore vital for Indonesia' economy. Air transport services are aimed to support the growth of the economic, trade and tourism sectors. It is the reason, Indonesia has issued permits for 247 domestic routes connecting 125 cities in Indonesia and for 57 international routes which connect 5 cities in 13 countries. Indonesia has recorded strong growth in passengers traffic since 2008 with an average of $15 \%$ per year, Indonesia's passenger traffic in 2011 was 114 million passengers. ${ }^{3}$

Indonesia has 233 airports including 29 airports serving international flights. Soekarno-Hatta International Airport is Indonesia's main gateway, which is also named as the $11^{\text {th }}$ busiest airport in the world by Airport Council International (ACI) in 2012 and the $4^{\text {th }}$ busiest in Asia with 51.1 million passengers in 2011. Average annual growth was $14 \%$ in the last 10 years. According to the Ministry of Communication (MOC), a new terminal in Soekarno-Hatta will be opened by 9 August $2016^{4}$ for a total volume of 62 million passengers per year. In December 2009, Forbes Traveler recognized Soekarno-Hatta International Airport as the second most punctual airport in the world with $89.2 \%$ of its flight departing on time, and $84.2 \%$ arriving on time.

There are 21 scheduled and 45 non-scheduled airlines registered and operating in Indonesia's main international carrier, Garuda Indonesia operated 81 aircraft to serve international and domestic routes. Recognizing the increased the performance at the international level, Garuda Indonesia was named "The World's Most Improved Airline" in 2010, followed by it achievement in 2012 as "World's Best Regional Airlines. ${ }^{5}$ This article intend to evaluate the contribution of Indonesia relating to international and regional civil aviation.

\section{Legal Ground of I Ndonesian Aviation Activities}

Chicago Convention of 1944 (the CC of 1944), ${ }^{6}$ signed at Chicago on 7 December 1944 as a constitution of international civil aviation consisted 22 Chapters and 96 Articles provides general principles such as sovereignty, territory; flight over territory of contracting States such as scheduled and non-scheduled flight, cabotage, pilotless of aircraft, prohibited areas, landing at custom airport, applicability of air regulation, rules of the air, entry and clearance regulations, prevention of spread of disease, airport and similar charges, search and rescue; nationality of aircraft such as dual registration, national law governing registration, display of marks, report of registration; measures to facilitate air navigation such as customs and immigration procedures,

\footnotetext{
${ }^{1}$ Lecturer of Law Faculty at the University of Tarumanagara

${ }_{3}^{2}$ Prof.(Emeritus), Lecturer of Law Faculty in the University of Tarumanagara

3 Indonesia's Civil Aviation Development, A paper submitted to Sixth Meeting of Worldwide Air Transport Conference, Montreal, 18 to 22 March 2013.

${ }^{4}$ Kompas Daily dated on 3 August 2016

${ }^{5}$ Ibid.

${ }^{6}$ For the text see Michael Milde Ed.,(1993) XVIII-Part II, Ann. Air \& Sp. L at 5-77

DOI: $10.9790 / 2834-1104044664 \quad$ www.iosrjournals.org $\quad 46 \mid$ Page
}


customs duty, aircraft in distress, investigation of accidents, exemption from seizure on patent claims, air navigation facilities; conditions to be fulfilled with respect to aircraft such as aircraft radio equipment, certificate of airworthiness, license of personnel, recognition of certificate, journey logbook, cargo restriction; international standard and recommended practices such as adoption of international standards and procedures, departures from international standard and recommended practices (SARP), endorsement of certificate, validity of endorsed certificate; the international civil aviation organization such as general assembly, council, air navigation commission; personnel; finance; other international arrangement etc.

Without disregards the other provisions, the most important in relation to this article are Articles 37 and 38 of the CC of 1944. Article 37 of the CC of 1944 provides that each contracting State undertakes to collaborate in securing the highest practicable degree of uniformity in regulations, standards, procedures, and organization in relation to aircraft, personnel, airways and auxiliary services in all matters in which such uniformity will facilitate and improve air navigation. For that purpose, ICAO shall adopt and amend from time to time, as may be necessary, SARP and procedures dealing with communications, airport, rules of the air, licensing, airworthiness, registration of aircraft, log book, maps and charts, customs and immigration, aircraft in distress, aircraft accident investigation and others matters, whilst Article 38 of the CC of 1944 provides that in the case the States cannot comply with the SARP provided by the ICAO shall, immediately, give notification to the ICAO of the differences between its own national regulations and the SARP.

\section{Contribution of Indonesia to International and Regional of Civil Aviation. \\ A. Coordination with ICAO}

Taking into consideration that Indonesia is a member of the CC of $1944,{ }^{7}$ Indonesia communicates close cooperation with the ICAO. This communication has been proven in relating to compliances of the recommendation provides by the ICAO in return the role of ICAO in assistance on providing technical assistance. ICAO has provided technical assistance to the Directorate General Air Communications (DGAC) Indonesia for some 40 years under the United Nations Development Program (UNDP) and Government of Indonesia cooperation, ${ }^{8}$ especially in major areas such as airworthiness; navigation and air traffic management; training center such as human resources development and capacity building; regulatory matters, airport and aerodrome; safety and security; industry development including airlines, aircraft manufactures, airports, aircraft maintenance; inspection, surveillance and audit. For the purpose of implementation, the ROI issued the CAA of 2009 of $2009 .^{9}$

\section{B. Civil Aviation Act of $\mathbf{2 0 0 9}$}

To implement the SARP provided by ICAO, the ROI issued the CAA of 2009. It came into force on 12 January 2009. The aims and objective of the CAA of 2009 is to promote the development of Indonesian air transportation. ${ }^{10}$ It regulates a host of matters related to aviation, from sovereignty in airspace, aircraft production, operation and airworthiness of aircraft to aviation security and safety, aircraft procurement, aviation insurance, the independence of aircraft accident investigation and the licensing of aviation professionals. The CAA of 2009 also regulates scheduled and non-scheduled air transportation, airline capital, the ownership of aircraft, aircraft leasing, fares, the liability of air carriers, air navigation facilities, airport authorities and services, and law enforcement related to air transportation.

In addition, the CAA of 2009 also has provisions aimed at supporting the development of national and international air transportation in Indonesia, including provisions regarding the creation of a public services institute to further those goals. ${ }^{11}$ Almost all the provisions of the CC of 1944 has been adopted by the CAA of 2009 for the purpose to implement the SARP provided by ICAO. Thus, Indonesia has fully complied with the CC of 1944.This legislation in line with the $38^{\text {th }}$ General Assembly Res.A38-4 which urges all member States to

\footnotetext{
${ }^{7}$ Indonesia adhered the Chicago Convention of 1944 on 27 April 1950, see Paul Stephen Dempsey Ed., (2005) XXX-Part I,Ann. Air \& Sp.L.at 52.

${ }^{8}$ Muzaffar Ismail on behalf of Santosa Eddy Wibowo, Indonesia Civil Aviation Growth and Technical Cooperation, Submitted to the Global Aviation Cooperation Symposium, ICAO Head Quarters, Montreal , 30 Sept-3 October 2014.

${ }^{9}$ Act Concerning Civil Aviation, Act No.1 of 2009, State Gazette of the ROI No.1 of 2009, Supplement State Gazette of the ROI Number 4956 [Civil Aviation Act 1 of 2009). Ministry of Transportation Republic of Indonesia, online: Directorate General of Civil Aviation http://hubud.dephub.go.id/?en/uu

${ }^{10}$ Ibid.

${ }^{11}$ Martono and Amad Sudiro, Current Air Transport Regulations In Indonesia, published in (2013) XXXVIII,Ann. Air \& Sp.L.at 55-90
} 
continue to examine the existing legislation and adjust as necessary or act laws and regulations to protect all the relevant safety data to the extent possible, on the legal and other guidance developed by ICAO. ${ }^{12}$

\section{Public International Air Law Regime}

1. Amendment of the $\mathrm{CC}$ of $\mathbf{1 9 4 4}$

With regard to the Civil Aviation Constitution of international air law, such as the CC of 1944, Indonesia has ratified on 27 April $1950,{ }^{13}$ and its amendment such as Protocol Relating to an Amendment to the Convention on International Civil Aviation (Article 93 bis), ${ }^{14}$ Protocol to an Amendment to the Convention on International Civil Aviation (Article 45) signed at Montreal On 14 June 1954, ${ }^{15}$ Protocol Relating to an Amendment to the Convention on International Civil Aviation [Article 489a)] signed at Montreal on 15 September $1962,{ }^{16}$ Protocol Relating to an Amendment to the International Civil Aviation (Final Clause-Russian Text) signed at Montreal, on 30 September 1977, ${ }^{17}$ Protocol Relating to an Amendment to the convention on International Civil Aviation (Article 83 bis) signed at Montreal on 6 October $1980,{ }^{18}$ Protocol Relating to an Amendment to the Convention on International Civil Aviation (Article 56), ${ }^{19}$ Protocol Relating to an Amendment to the Convention on International Civil Aviation [Article 509a)] signed at Montreal on 26 October $1990 .^{20}$

\section{Tokyo Convention of 1963, The Hague Convention of 1970 and Montreal Convention of 1971}

With regard to penal air law instruments, Indonesia has ratified Tokyo Convention of 1963, signed at Tokyo on 14 September $1963,{ }^{21}$ The Hague Convention of 1970 signed at The Hague on 16 December $1970^{22}$ and the Montreal Convention of 1971, signed at Montreal on 23 September 1971. ${ }^{23}$ It is worthwhile to note here with regard to the Hague Convention of 1970, Indonesia made reservation to paragraph 1 of Article 12 of the Convention.

In relating to Tokyo Convention of 1963, the Director General of Air Communications (DGAC), Ministry of Communications (MOC), Mr Herry Bakti, actively participated in the Diplomatic Conference to Adopt the Proposed Draft Text of the Protocol to the Tokyo Convention of 1963, at the Headquarters of the ICAO, Montreal , 26 March 2014-4 April 2014. As expressly by the President of the Council of ICAO, Dr. O. B. Aliu during the opening, the Diplomatic Conference to aims modernize the judicial aspects concerning disruptive and unruly passengers as stipulated by the convention on Offences and Certain Other Acts Committed on Board Aircraft.

\section{Cape Town Convention of 2001}

On 16 November 2001, a Diplomatic Conference held in Cape Town, South Africa, under the cosponsorship of the ICAO and the International Institute for the Unification of Private Law ("UNIDROIT"), adopted an international treaty ("Cape Town Convention-CTC of 2001") specifically designed to facilitate assetbased financing and leasing. Fifty-three (53) States signed the Final Act of that Conference. The CTC of 2001 (technically, the Convention on International Interests in Mobile Equipment, ("Convention"), as applied to aircraft equipment through a protocol ("Protocol"), came into force three months after the eight (8) ratification, acceptance, or accession to, the Protocol.

\footnotetext{
${ }^{12}$ See $38^{\text {th }}$ General Assembly Resolution, Montreal, 24 September -4 October 2013 A38-4.

${ }^{13}$ Chicago Convention of 1944, supra note 6 p.52

${ }^{14}$ Indonesia ratified on 17 July 1961,Ibid ., supra note 6 page 84.

${ }^{15}$ Indonesia ratified on 24 November 1959, Ibid. supra note 6 page 92.

${ }^{16}$ Indonesia ratified on 19 February 1963, Ibid.,supra note 6 page 100.

${ }^{17}$ Indonesia ratified on 20 November 1990, Ibid., supra note 6 page 118

${ }^{18}$ Indonesia ratified on 5 August 1994. Ibid. supra note 6 page 136.

${ }^{19}$ Indonesia ratified on 6 November 1995, Ibid., supra note 6, at 154

${ }^{20}$ Ibid. at 162

${ }^{21}$ Chicago Convention of 1944, supra note 6 at 185-193.

${ }^{22}$ Ibid. at 203-209

${ }^{23}$ Convention on Offences and Certain Other Acts Committed on Board Aircraft, signed at Tokyo 1963, Convention for the Suppression of Unlawful Seizure of Aircraft, signed at the Hague on 16 December 1970 and Convention for the Suppression of Unlawful Acts Against the Safety of Civil Aviation, signed at Montreal on 23 September 1971 has been ratified Indonesia on 27 August 1976 by Act concerning Ratification of Tokyo Convention of 1963, The Hague Convention of 1970 and Montreal Convention of 1971, Act. Number 2 of 1976 The Republic of Indonesia.
} 
The CTC of 2001 creates a uniform international legal framework to protect investors in aircraft objects. It provides an International Registration for creditors and debtors to register their security interests and creates a set of basic remedies in the event of debtor default. The Protocol complements the CTC of 2001 and adopts its provisions to meet the particular requirements of financing mobile equipment such as aircraft. For example, it provides additional remedies for creditors, such as the ability to request the deregistration and export of an aircraft object. These measures increase the security of creditors and reduce their risks, which may lead to reduce the cost and more accessible financing of aircraft objects for those countries that are party to the Cape Town Convention of 2001. ${ }^{24}$

\section{Content of the CTC of 2001}

The Cape Town Convention of 2001 (CTC of 2001) consisted of fourteen (14) Chapters and sixty-two (62) Articles namely Chapter I provides sphere of application and general provisions; Chapter II provides constitutional of an international interest; Chapter III provides default remedies; Chapter IV provides international registration system; Chapter V provides other matters relating to registration; Chapter VI provides privileges and immunities of the supervisory authority and the registrar; Chapter VII provides liability of the registrar; Chapter VIII provides effects of an international interest as against third parties; Chapter IX provides assignments of associated rights and international interests, rights of subrogation; Chapter X provides rights or interest subject to declaration without registration; Chapter XI provides application of the convention to sales; Chapter XII provides jurisdiction; Chapter XIII provides relationship with other convention, and Chapter XV provides final provision.

\section{International Interest in Aircraft}

With regard to the international interest in aircraft is stipulated in Articles 71 to 82 of the CAA of 2009. In accordance with the CAA of 2009 an aircraft object may be borne with international interest arising as a result of security, title reservation and leasing agreements ${ }^{25}$ based on the law of choice made by the parties to the agreements. $^{26}$ In the case of the agreement applicable Indonesian laws, the agreement must be drawn in an authentic deed containing at least identities of all the parties, the aircraft objects and the right and obligations of the parties. ${ }^{27}$

A debtor may issue an authorization for deregistration request to the creditor for the purpose of applying for deregistration and export on the aircraft or helicopter already obtaining an Indonesian registration marks and nationality. Such power of attorney shall be acknowledged and recorded by MOC and may not be annulled without consent of the creditor. In addition, the power of attorney of deregistration shall remain valid at the time the debtor declared default or in a condition of inability to pay debts (insolvent). The creditor shall be the only party authorized to submit a request for annulment on the aircraft or helicopter registration in accordance with the terms in the authorization for deregistration requested. ${ }^{28}$

In the case the debtor breaches the contract, the creditor may submit a request to the MOC according to the power of attorney of deregistration, to annul/cancel the registration and export of the aircraft or helicopter. Based on the creditor's request, the MOC shall be obligated to annul/cancel the registration marks and nationality of the aircraft or helicopter no later than 5 (five) working days after the request is received. ${ }^{29}$ The MOC and other government agencies shall have to assist and expedite any recovery attempt contemplated by any creditor based on an agreement. ${ }^{30}$ Creditor's and recovery attempt shall arise at the time of signing of the agreement by the parties.

International interests, including every transfer and/or subordination of those interests, shall receive the priority status at the time of registration of the interest to the International registration office. ${ }^{31}$ In the case the debtor breaches the agreement, the creditor may obtain a decision form the state court for temporary action based on the agreement without prior submission of law suit against the main case to enforce the claims in Indonesia and without having all parties undergoing mediation ordered by the court. The court decision shall be implemented within the period stated in the declaration made by the government regarding the stated convention and protocol. ${ }^{32}$

\footnotetext{
${ }^{24}$ Regulation Impact Statement "Implementation of the Cape Town Convention, paper unpublished.

${ }^{25}$ Article 71

${ }^{26}$ Article 72

${ }^{27}$ Article 73

${ }^{28}$ Article 74

${ }^{29}$ Article 75

${ }^{30}$ Article 76

${ }^{31}$ Article 78

${ }^{32}$ Article 79
}

DOI: $10.9790 / 2834-1104044664 \quad$ www.iosrjournals.org $\quad 49 \mid$ Page


The court, curator, bankruptcy committee, and/or debtor shall transfer the possession of aircraft object to the rightful creditor within the period stipulated by the government. ${ }^{33}$ Certain invoices shall have priority against other invoices from holders of international interests registered on an aircraft object. The provisions of the CTC of 2001 and the Protocol to the Matters Specific to Aircraft Equipment, wherein Indonesia is a party to, shall have legal standing in Indonesia and shall become lex specialist in legal term.

\section{a. Legal Ground}

\section{The Implementation of the CTC of 2001 and Its Protocol in Indonesia}

Indonesia has ratified the CTC of 2001 and its protocol, ${ }^{34}$ by the Presidential Decree No. 8/ 2007. This Convention is one of the reasons Indonesia changed the Civil Aviation Act of 1992 by the Civil Aviation Act of 2009, and this is reflected in the explanation chapter of the CAA of 2009. The CTC of 2001 and its Protocol, regulates the four elements in Security Interest on Mobile Equipment specifically on Aircraft namely the International Interest, the International Registration, the Priority Rules and the Default Remedies. These four elements should be implemented in the national laws of Indonesia as a state party to the CTC of 2001. The CAA of 2009 has incorporated the elements of the CTC of 2001 and its Protocol in Chapter IX, from Article 71 to 82. This ratification to the CTC of 2001 and Protocol will support the aircraft procurement for the national airlines of Indonesia. ${ }^{35}$

Beside the CAA of 2009, other international obligations arising out of the CTC of 2001 has been set up. Those regulations are Ministerial Decree Number KM 49 of 2009 Civil Aviation Safety Regulation Part 47 on Registration of Aircraft ${ }^{36}$ and Director General Air Communication (DGAC) Regulations No. SKEP/166/VII/2009 Staff Instruction (SI) regarding IDERA (Irrevocable Deregistration and Export Request Authorization).

\section{b. Definition}

The definitions contained in the Indonesia legislation are very similar to the definitions in the CTC of 2001 and its associated Protocol to the Convention on Interest Mobile Equipment on Matters Specific to Aircraft Equipment. ${ }^{37}$ Thus, "aircraft objects" are aircraft frame or skeletons, air engines, and helicopters. An "aircraft frame" or skeleton is a skeleton of an aircraft (other than those frames used for military, customs, or police aircraft), provided that an aircraft engine suitable for the aircraft frame/skeleton is installed into it, and that it will be certified by an authorized aviation agency for transporting at least eight persons, including the crew, or goods weighing more than $2,750 \mathrm{~kg}$, along with all of its installed equipment, components, and other devices, which are either built-in or attached to the aircraft (other than the aircraft engine) and all data, guide books and notes associated with it. ${ }^{38}$

"Aircraft engines" are engines (other than those used for military, customs, or police force aircraft) moved by jet propulsion or turbine or piston power. Inn case of an aircraft engine with a propulsion jet, it must have a thrust/propulsion power of at least $1,750 \mathrm{lbs}$ or the equivalent to qualify under this definition. Aircraft engine are driven by a turbine or piston, and they must have average capacity of at least 550 horsepower similar for take-off, along with all modules and installed equipment, components and other devices, built-in or attached to the aircraft, and all the data, guide books and notes associated with it. ${ }^{39}$

A helicopter is a certain helicopter (not used for military, customs or police use) certified by an authorized aviation agency for transporting at least five persons, including the air crew, or goods more than $450 \mathrm{~kg}$ along with all the installed equipment and devices, whether built-in or attached to the helicopter (including the rotors) and all data, guide books and notes associated with it. ${ }^{40}$ Meanwhile, an "international

\footnotetext{
${ }^{33}$ Article 80

${ }^{34}$ Convention on International Interest in Mobile Equipment, 16 November 2001, 2307 UNTS 2855, UN Doc. .A/AC105/C.2/2002/CRP.3 (entered into force 1 April 2004)[Cape Town Convention].

${ }^{35}$ Based on this provision, Indonesian airlines have procurement no less than 299 aircraft from Boeing and Airbus to fulfill the country's aircraft needs.

${ }^{36}$ Ministerial Decree Concerning Aircraft Registration. Ministerial Decree No.KM 49 of 2009 (10 June 2009) [Ministerial Decree]

${ }^{37}$ Protocol to the Convention on Interest Mobile Equipment on Matters Specific to Aircraft Equipment, 16 November 2001 (entered into force 1 March 2006).

${ }^{38}$ See Civil Aviation Act, supra note 9, art 1(2)(e)

${ }^{39} \mathrm{Ibid}$, art 71, explanatory notes. See also Protocol, supra, arts 1(2)(b)(1) and 1(2)(b)(ii)

${ }^{40}$ Ibid. 
interest" is an interest obtained by a creditor arising from a security agreement, the reservation agreement and/or leasing agreement that is subject to the Convention on International Interest in Mobile Equipment and the Protocol to the Convention on Interests in Mobile Equipment on Matters Specific to Aircraft Equipment. ${ }^{41}$

A "security to implement the SARP provided by ICAO, the ROI issued the CAA of 2009. It came into force on 12 January 2009. The aims and objective of the CAA of 2009 is to promote the development of Indonesian air transportation. ${ }^{42}$ It regulates a host of matters related to aviation, from sovereignty in airspace, aircraft production, operation and airworthiness of aircraft to aviation security and safety, aircraft procurement, aviation insurance, the independence of aircraft accident investigation and the licensing of aviation professionals. The CAA of 2009 also regulates scheduled and non-scheduled air transportation, airline capital, the ownership of aircraft, aircraft leasing, fares, the liability of air carriers, air navigation facilities, airport authorities and services, and law enforcement related to air transportation.

In addition, the CAA of 2009 also has provisions aimed at supporting the development of national and international air transportation in Indonesia, including provisions regarding the creation of a public services institute to further those goals. ${ }^{43}$ Almost all the provisions of the CC of 1944 has been adopted by the CAA of 2009 for the purpose to implement the SARP provided by ICAO. Thus, Indonesia has fully complied with the CC of 1944.This legislation in line with the $38^{\text {th }}$ General Assembly Res.A38-4 which urges all member States to continue to examine the existing legislation and adjust as necessary or act laws and regulations to protect all the relevant safety data to the extent possible, on the legal and other guidance developed by ICAO. ${ }^{44}$

ratified on 27 April 1950, ${ }^{45}$ and its amendment such as Protocol Relating to an Amendment to the Convention on International Civil Aviation (Article 93 bis) ${ }^{46}$ Protocol to an Amendment to the Convention on International Civil Aviation (Article 45) signed at Montreal 0n 14 June 1954, ${ }^{47}$ Protocol Relating to an Amendment to the Convention on International Civil Aviation [Article 489a)] signed at Montreal on 15 September $1962,{ }^{48}$ Protocol Relating to an Amendment to the International Civil Aviation (Final Clause-Russian Text) signed at Montreal, on 30 September $1977,{ }^{49}$ Protocol Relating to an Amendment to the convention on International Civil Aviation (Article 83 bis) signed at Montreal on 6 October $1980,{ }^{50}$ Protocol Relating to an Amendment to the Convention on International Civil Aviation (Article 56), ${ }^{51}$ Protocol Relating to an Amendment to the Convention on International

With regard to penal air law instruments, Indonesia has ratified Tokyo Convention of 1963, signed at Tokyo on 14 September $1963,{ }^{52}$ The Hague Convention of 1970 signed at The Hague on 16 December $1970^{53}$ and the Montreal Convention of 1971, signed at Montreal on 23 September $1971 .{ }^{54}$ It is worthwhile to note here with regard to the Hague Convention of 1970, Indonesia made reservation to paragraph 1 of Article 12 of the Convention.

In relating to Tokyo Convention of 1963, the Director General of Air Communications (DGAC), Ministry of Communications (MOC), Mr Herry Bakti, actively participated in the Diplomatic Conference to Adopt the Proposed Draft Text of the Protocol to the Tokyo Convention of 1963, at the Headquarters of the

\footnotetext{
${ }^{41}$ Cape Town Convention, supra note 25 , art I(o)

${ }^{42}$ Ibid.

${ }^{43}$ Martono and Amad Sudiro, Current Air Transport Regulations In Indonesia, published in (2013) XXXVIII,Ann. Air \& Sp.L.at 55-90
}

${ }^{44}$ See $38^{\text {th }}$ General Assembly Resolution, Montreal, 24 September - 4 October 2013 A38-4.

${ }^{45}$ Chicago Convention of 1944, supra note 6 p.52

${ }^{46}$ Indonesia ratified on 17 July 1961,Ibid ., supra note 6 page 84.

${ }^{47}$ Indonesia ratified on 24 November 1959, Ibid. supra note 6 page 92.

${ }^{48}$ Indonesia ratified on 19 February 1963, Ibid., supra note 6 page 100.

${ }^{49}$ Indonesia ratified on 20 November 1990, Ibid., supra note 6 page 118

${ }^{50}$ Indonesia ratified on 5 August 1994. Ibid. supra note 6 page 136.

${ }^{51}$ Indonesia ratified on 6 November 1995, Ibid., supra note 6, at 154

${ }^{52}$ Chicago Convention of 1944, supra note 6 at 185-193.

${ }^{53}$ Ibid. at 203-209

${ }^{54}$ Convention on Offences and Certain Other Acts Committed on Board Aircraft, signed at Tokyo 1963, Convention for the Suppression of Unlawful Seizure of Aircraft, signed at the Hague on 16 December 1970 and Convention for the Suppression of Unlawful Acts Against the Safety of Civil Aviation, signed at Montreal on 23 September 1971 has been ratified Indonesia on 27 August 1976 by Act concerning Ratification of Tokyo Convention of 1963, The Hague Convention of 1970 and Montreal Convention of 1971, Act. Number 2 of 1976 The Republic of Indonesia. 
ICAO, Montreal , 26 March 2014-4 April 2014. As expressly by the President of the Council of ICAO, Dr. O. B. Aliu during the opening, the Diplomatic Conference to aims modernize the judicial aspects concerning disruptive and unruly passengers as stipulated by the convention on Offences and Certain Other Acts Committed on Board Aircraft

On 16 November 2001, a Diplomatic Conference held in Cape Town, South Africa, under the cosponsorship of the ICAO and the International Institute for the Unification of Private Law ("UNIDROIT"), adopted an international financing and leasing. Fifty-three (53) States signed the Final Act of that Conference. The CTC of 2001 (technically, the Convention on International Interests in Mobile Equipment, ("Convention"), as applied to aircraft equipment through a protocol ("Protocol"), came into force three months after the eight (8) ratification, acceptance, or accession to, the Protocol.

The CTC of 2001 creates a uniform international legal framework to protect investors in aircraft objects. It provides an International Registration for creditors and debtors to register their security interests and creates a set of basic remedies in the event of debtor default. The Protocol complements the CTC of 2001 and adopts its provisions to meet the particular requirements of financing mobile equipment such as aircraft. For example, it provides additional remedies for creditors, such as the ability to request the deregistration and export of an aircraft object. These measures increase the security of creditors and reduce their risks, which may lead to reduce the cost and more accessible financing of aircraft objects for those countries that are party to the Cape Town Convention of 2001..$^{55}$

The Cape Town Convention of 2001 (CTC of 2001) consisted of fourteen (14) Chapters and sixty-two (62) Articles namely Chapter I provides sphere of application and general provisions; Chapter II provides constitutional of an international interest; Chapter III provides default remedies; Chapter IV provides international registration system; Chapter V provides other matters relating to registration; Chapter VI provides privileges and immunities of the supervisory authority and the registrar; Chapter VII provides liability of the registrar; Chapter VIII provides effects of an international interest as against third parties; Chapter IX provides assignments of associated rights and international interests, rights of subrogation; Chapter $\mathrm{X}$ provides rights or interest subject to declaration without registration; Chapter XI provides application of the convention to sales; Chapter XII provides jurisdiction; Chapter XIII provides relationship with other convention, and Chapter XV provides

With regard to the international interest in aircraft is stipulated in Articles 71 to 82 of the CAA of 2009. In accordance with the CAA of 2009 an aircraft object may be borne with international interest arising as a result of security, title reservation and leasing agreements ${ }^{56}$ based on the law of choice made by the parties to the agreements. ${ }^{57}$ In the case of the agreement applicable Indonesian laws, the agreement must be drawn in an authentic deed containing at least identities of all the parties, the aircraft objects and the right and obligations of the parties. ${ }^{58}$

A debtor may issue an authorization for deregistration request to the creditor for the purpose of applying for deregistration and export on the aircraft or helicopter already obtaining an Indonesian registration marks and nationality. Such power of attorney shall be acknowledged and recorded by MOC and may not be annulled without consent of the creditor. In addition, the power of attorney of deregistration shall remain valid at the time the debtor declared default or in a condition of inability to pay debts (insolvent). The creditor shall be the only party authorized to submit a request for annulment on the aircraft or helicopter registration in accordance with the terms in the authorization for deregistration requested. ${ }^{59}$

In the case the debtor breaches the contract, the creditor may submit a request to the MOC according to the power of attorney of deregistration, to annul/cancel the registration and export of the aircraft or helicopter. Based on the creditor's request, the MOC shall be obligated to annul/cancel the registration marks and nationality of the aircraft or helicopter no later than 5 (five) working days after the request is received. ${ }^{60}$ The MOC and other government agencies shall have to assist and expedite any recovery attempt contemplated by any creditor based on an agreement. ${ }^{61}$ Creditor's and recovery attempt shall arise at the time of signing of the agreement

International interests, including every transfer and/or subordination of those interests, shall receive the priority status at the time of registration of the interest to the International registration office. ${ }^{62}$ In the case the debtor breaches the agreement, the creditor may obtain a decision form the state court for temporary action

\footnotetext{
${ }^{55}$ Regulation Impact Statement "Implementation of the Cape Town Convention, paper unpublished.

${ }^{56}$ Article 71

57 Article 72

${ }^{58}$ Article 73

${ }^{59}$ Article 74

${ }^{60}$ Article 75

${ }^{61}$ Article 76

${ }^{62}$ Article 78
} 
based on the agreement without prior submission of law suit against the main case to enforce the claims in Indonesia and without having all parties undergoing mediation ordered by the court. The court decision shall be implemented within the period stated in the declaration made by the government regarding the stated convention and protocol. ${ }^{63}$

The court, curator, bankruptcy committee, and/or debtor shall transfer the possession of aircraft object to the rightful creditor within the period stipulated by the government. ${ }^{64}$ Certain invoices shall have priority against other invoices from holders of international interests registered on an aircraft object. The provisions of the CTC of 2001 and the Protocol to the Matters Specific to Aircraft Equipment, wherein Indonesia is a party to, shall have legal standing in Indonesia and shall become lex specialist in legal term.

Indonesia has ratified the CTC of 2001 and its protocol, ${ }^{65}$ by the Presidential Decree No. 8/ 2007. This Convention is one of the reasons Indonesia changed the Civil Aviation Act of 1992 by the Civil Aviation Act of 2009, and this is reflected in the explanation chapter of the CAA of 2009. The CTC of 2001 and its Protocol, regulates the four elements in Security Interest on Mobile Equipment specifically on Aircraft namely the International Interest, the International Registration, the Priority Rules and the Default Remedies. These four elements should be implemented in the national laws of Indonesia as a state party to the CTC of 2001. The CAA of 2009 has incorporated the elements of the CTC of 2001 and its Protocol in Chapter IX, from Article 71 to 82. This ratification to the CTC of 2001 and Protocol will support the aircraft procurement for the national airlines of Indonesia. ${ }^{66}$

Beside the CAA of 2009, other international obligations arising out of the CTC of 2001 has been set up. Those regulations are Ministerial Decree Number KM 49 of 2009 Civil Aviation Safety Regulation Part 47 on Registration of Aircraft ${ }^{67}$ and Director General Air Communication (DGAC) Regulations No. SKEP/166/VII/2009 Staff Instruction (SI) regarding IDERA (Irrevocable Deregistration and Export Request Authorization

The definitions contained in the Indonesia legislation are very similar to the definitions in the CTC of 2001 and its associated Protocol to the Convention on Interest Mobile Equipment on Matters Specific to Aircraft Equipment. ${ }^{68}$ Thus, "aircraft objects" are aircraft frame or skeletons, air engines, and helicopters. An "aircraft frame" or skeleton is a skeleton of an aircraft (other than those frames used for military, customs, or police aircraft), provided that an aircraft engine suitable for the aircraft frame/skeleton is installed into it, and that it will be certified by an authorized aviation agency for transporting at least eight persons, including the crew, or goods weighing more than $2,750 \mathrm{~kg}$, along with all of its installed equipment, components, and other devices, which are either built-in or attached to the aircraft (other than the aircraft engine) and all data, guide books and notes associated exchange

"Aircraft engines" are engines (other than those used for military, customs, or police force aircraft) moved by jet propulsion or turbine or piston power. Inn case of an aircraft engine with a propulsion jet, it must have a thrust/propulsion power of at least $1,750 \mathrm{lbs}$ or the equivalent to qualify under this definition. Aircraft engine are driven by a turbine or piston, and they must have average capacity of at least 550 horsepower similar for take-off, along with all modules and installed equipment, components and other devices, built-in or attached to the aircraft, and all the data, guide books and notes associated with it. ${ }^{69}$

A helicopter is a certain helicopter (not used for military, customs or police use) certified by an authorized aviation agency for transporting at least five persons, including the air crew, or goods more than $450 \mathrm{~kg}$ along with all the installed equipment and devices, whether built-in or attached to the helicopter (including the rotors) and all data, guide books and notes associated with it. ${ }^{70}$ Meanwhile, an "international interest" is an interest obtained by a creditor arising from a security agreement, the reservation agreement and/or

\footnotetext{
${ }^{63}$ Article 79

${ }^{64}$ Article 80

${ }^{65}$ Convention on International Interest in Mobile Equipment, 16 November 2001, 2307 UNTS 2855, UN Doc. .A/AC105/C.2/2002/CRP.3 (entered into force 1 April 2004)[Cape Town Convention].

${ }^{66}$ Based on this provision, Indonesian airlines have procurement no less than 299 aircraft from Boeing and Airbus to fulfill the country's aircraft needs.

${ }^{67}$ Ministerial Decree Concerning Aircraft Registration. Ministerial Decree No.KM 49 of 2009 (10 June 2009) [Ministerial Decree]

${ }^{68}$ Protocol to the Convention on Interest Mobile Equipment on Matters Specific to Aircraft Equipment, 16 November 2001 (entered into force 1 March 2006)

${ }^{69} \mathrm{I}$ bid, art 71, explanatory notes. See also Protocol, supra, arts 1(2)(b)(1) and 1(2)(b)(ii)

${ }^{70}$ Ibid.
} 
leasing agreement that is subject to the Convention on International Interest in Mobile Equipment and the Protocol to the Convention on Interests in Mobile Equipment on Matters Specific to Aircraft Equipment. ${ }^{71}$

$y$ agreement' is an agreement whereby the charger of an aircraft object gives or agrees to give to the charge of the security agreement an interest (including ownership or /title) in the aircraft object in order to guarantee delivery of obligations incurred or to be incurred by the charger or third party. ${ }^{72}$ Meanwhile, a 'title reservation agreement' is a sale agreement for any aircraft object with a provision that ownership/title shall be transferred until the requirements under the agreement have been met. ${ }^{73} \mathrm{~A}$ "leasing agreement" is an agreement whereby the lessor gives his/her rights to the lessee to possess the aircraft object (with or without the option to purchase) in exchange for a rent or any other payment as compensation. ${ }^{74}$

\section{c. Applicability}

In general, Articles 71 to 82 of the CAA of 2009 , regulate a number of principles mentioned in the CTC of 2001 and its Protocol. Article 71 of the CAA of 2009 defines the aircraft as an object of an international interest as a result of a security agreement, a title reservation agreement, and/or a leasing agreement. Aircraft objects include airframe, aircraft engine and helicopter as regulated in the CTC of 2001. Furthermore, the definition of airframe, aircraft engine and helicopter can be found in the explanation chapter of the CAA of 2009. By this article, the definition of an International Interest, means a (security) interest obtained by a creditor based on security agreements, a title reservation agreement, and/or a leasing agreement, under the CTC of 2001.

Article 72 of the CAA of 2009 gives the right to the parties to choose the choice of law and jurisdiction of the agreement as regulated in Article 71 of the CAA of 2009. This agreement being in essence an international contract, should consider the principle on choice of law and choice of jurisdiction based on private international law. If the agreement is made under Indonesian Law, it should be made on an authentic deed which containts the identity of the parties, the identity of the aircraft objects and the rights and duties of the parties, as stipulated in Article 73 of the CAA of 2009.

In the implementation of the agreement between the debtor and creditor which establises an international interest, when a debtor is in default or does not comply to the obligations of the agreement, the creditor may request the deregistration of the aircraft to the MOC with an the application of an irrevocable deregistration and export authorizing request. The deregistration can be enforced only by a power of attorney made by the debtor, which has to be acknowledged by the MOC and can not be annulled without the approval from the creditor as regulated in Article 74 of the CAA of 2009. Upon the creditor's request, the MOC shall remove the registration and the nationality of the aircraft or helicopter within a maximum of 5 (five) days from the request. These provisions are regulated in article 75 of the CAA of 2009. Articles 74 and 75 of the CAA of 2009 provide default remedies, when a default is caused by the debtors, and therefore giving rights to the creditors to submit the deregistration request to the MOC. Aricle 76 of the CAA of 2009 provides the remedies to be enforced by the MOC and the assistance of other related ministers to expedite the enforcement of those remedies. Remedies and creditor rights referred to in the previous articles are established upon the signing of the agreement by the parties in accordance with Article 77 of the CAA of 2009.

The International interest registered in the international registration has priority over other interests, including national interests in accordance to the Article 78 of the CAA of 2009. The International Registration is the facility managed by the ICAO. Furthermore, Article 79 of the CAA of 2009 provides in the situation of a debtor's default, the creditors may request provisional measures from the court based on the agreement mentioned in Article 71 of the CAA of 2009 without the submission of the case to be decided in the Indonesian court and without complying to the mediation procedure required in the general courts. These measures are in line with the declaration made by Indonesia when ratifying the CTC of 2001.

In the situation of a debtor's bankruptcy, the court, the curator, and/ or debtor shall hand over the control of the aircraft object to the creditor within the time limit provided by the Law. In the situation of a debtor's bankruptcy, a number of invoices may have priority over the international interest of the aircraft object. This regulation on bankruptcy is regulated in Article 80 and 81 of the Civil Aviation Act of 2009. These regulations differ from the Indonesian existing law on bankruptcy and hence needs to be harmonized.

Article 82 of the CAA of 2009 provides that the international convention on International Interest on mobile equipment and the Aircraft Protocol, are legally binding to Indonesia and shall be implemented as lex-

\footnotetext{
${ }^{71}$ Cape Town Convention, supra note 25, art I(o)

${ }^{72}$ Ibid., art I(ii)

${ }^{73}$ Ibid. , art I(II)

${ }^{74}$ Civil Aviation Act, supra note 9, art 71; Martono K and Amad Sudiro, supra note 11, at 84; See also Cape Town Convention, supra note 25, art I(q).
} 
specialist in Indonesian Law. In the Explanation Chapter, the definition of lex specialis means that in the case of inconsistency or discrepancy between the provisions of the Convention, protocols and declarations with Indonesian Law, the provisions of the Convention, the Protocol and the declaration shall prevail.

\section{The Most Important Provisions}

In line with the Declarations Indonesia made when ratifying the CTC of 2001, it is worthwhile to note here that the most important provision related to:

(1) Declaration to Article 39(1) (a) and (b) relating to non-consensual rights or interests which according to Indonesian Law have priority, such as the wages of workers, taxation claims and claims of services in respect of an aircraft object; and Declaration to Article 40, regarding recordation non-consensual rights and interest; ${ }^{75}$

(2) Declaration to Article 53 regarding determination of courts for the purpose of Article 1 and Chapter XII on Jurisdiction and Article 13(1)(a),(b),(c) and Article (4) on Relief pending final Determination to obtain from a court a speedy relief by the creditor for the preservation of the object and its value, which should be read in line with Article 8 on Remedies of Chargee; ${ }^{76}$

(3) Declaration to Article 54 (2), regarding Remedies, whereby a Contracting State shall declare whether or not any remedy is available to the creditor under any provision of this Convention which is not there expressed to require application to the Court may be exercised only with leave of the Court;

(4) Article XXX(1) re Article VIII, re Article XII, re Article XIII regarding the application of Article VIII on Choice of Law, Article XII on Insolvency assistance and Article VIII on deregistration/export request authorization; (5) Article XXX(2) re Article X regarding the application of Article X(2) on the speedy relief means; (6) Article XXX(3) re Article XI making effective alternative A for Indonesia. ${ }^{77}$

\section{The Advantages to Ratify the CTC of 2001}

Some Indonesian airlines have taken the advantages of the CTC of 2001 and its Protocol, for the purpose to facilitate aircraft financing, guarantees, and securities, which are useful for fleet modernization. In terms of the economic results, the CTC of 2001 has been very helpful for Indonesian airlines; between 2009 and 2013, Indonesian national airlines have procured at least 299 aircraft with the support of the CAA of 2009 which is supposed to incorporate the financing facilities provided by the CTC of 2001 and its Protocol.

\section{The Benefit of the CTC of 2001}

The CTC of 2001 will reduce risk applicable to asset-based financing and leasing transactions by establishing an international legal framework, backed by convention relations to and where necessary, implementing national laws. The risk of reduction will increase the availability and reduce the cost of aviation credit, thus broadening the spectrum of financing alternatives available to aircraft operators.

The CTC of 2001 benefit for the government, airlines, commercial aircraft manufacturers and their supplier, aviation industry investors and passengers and other and users. The beneficiaries of the government are first through reduced debt levels to governments whose credit in the form of sovereign guarantees or national debt is used to finance aircraft acquisitions, secondly as risk reductions to government providing export credit supporting aircraft sales, and thirdly to enhance privatization potential where applicable, whilst the beneficiaries for the airlines, is through reduced financing costs and enhanced access to funds and funding sources, increased operating efficiency and improved profitability. ${ }^{78}$

The benefit for commercial aircraft manufacturers and their supplies is through higher sales, output and employment levels, as well as expanded markets, whilst the benefit for aviation industry investor is through increased returns on, and higher valuations of, investments, as well as enhanced security and the benefit for passengers and other and users is to by-pass-through price reductions and increased levels of services. The costsavings and external debt-level reduction benefits are slanted in favor of developing economics, whose systems do not currently reflect asset-based financing principles. In these countries, the CTC of 2001 would generate the greater relative improvement. Conversely, the fleet planning, export and employment related benefits are, as a general proposition, slanted in favor of developed economies.

\footnotetext{
${ }^{75}$ Mieke Komar Kantaatmadja, The 2001 Cape Town Convention on International Interest in Mobile Equipment/the Aviation Protocol and Relevant Issues in Indonesian Aviation Law. Volume 8, Number 4 July 2011,p.633 [hereinafter Mieke Komar Kantaatmadja].

${ }^{76}$ Ibid.

${ }^{77}$ Ibid.

${ }^{78}$ Cape Town Convention of 2001, supra note 25, see also LON18625548/1,p.3
} 


\section{a. General Indications}

\section{The Best Practices}

Indonesia as a state party of the CTC of 2001 and its protocol has an obligation to implement the rules of the CTC of 2001 and its Protocol in the CAA of 2009. As earlier discussed the objectives of the CTC of 2001 is to facilitate the airlines aircraft procurement, to obtain the economic advantages such as reducing the cost of the procurement. On the other hand, to obtain the economic advantages from the CTC of 2001, a number of documents are required to be prepared by debtors and creditors. The implementation of the CTC of 2001 and its protocol in Indonesia, is based on Articles 71 to 82 of the CAA of 2009, Presidential Decree No. 8/ 2007 as the ratification instrument which contains the declarations, Ministerial Decree KM No. 49/ 2009 about IDERA.

With regard to the implementation of IDERA, the International Interest and the International Registration, Enny Purnomo Widya as a Partner of Mochtar Karuwin and Komar Law Firm, ${ }^{79}$ said that in practice our national laws are sufficient enough to implement the obligation based on the CTC of 2001 and Its Protocol. So far, the important thing is the implementation of IDERA stipulated in Articles 74 and 75 of the CAA of 2009. Based on these articles, there are two kinds of documents that should be prepared, after the airline has procured a new aircraft object with the right in the aircraft, registered as an international interest. The documents are the consent letter between the parties or the agreement that establishes the international interest and secondly, the power of attorney that should be acknowledged by the MOC.

\section{b. Garuda Indonesia Experiences}

Garuda Indonesia, as one of the national airlines in Indonesia, do not have so far any experience in regard with deregistration. It is means that they were able to comply with the obligations of the agreement, which establishes an international interest of rights. In line with the Garuda Indonesia experience, the implementation of the CTC of 2001 and its Protocol has not been tested in practice, specifically with the deregistration request.

\section{c. The Successful of Other Airlines}

Furthermore it is interesting to look at one of the successful airlines established in Indonesia in recent years. Lion Air is a privately owned airline founded in 1999, which today is the largest privately domestic carrier in Indonesia. The airline's success owes much to purchase of a new generation of Boeing aircraft, which have lower operating costs, which in turn translates to lower fares. Indonesia's ratification of the CTC of 2001 and the associated Protocol greatly assisted Lion Air's growth and expansion, as it provided an internationally recognized standard on the rights of creditors should a debtor (in this case, an airline) default or become insolvent. $^{80}$

\section{The Obstacle of Implementation}

The obstacle of the implementation of this regulation is the time limit to obtain the acknowledgement from the MOC. It is supposed to be only 5 days, but in fact, it could be more than 5 days. The problem is in the time limit, when exceeded it may cause a potential default, and harm the rights of the creditor for requesting the deregistration of the aircraft to the MOC. The mechanism of IDERA can be enforced in the process of a leasing agreement, restructuring and refinancing of the aircraft. In the case of bankruptcy and the regulations related to bankruptcy in Indonesia in general, prove to be contrary to the bankruptcy process in IDERA. ${ }^{81}$ With regards to time limit, it shall be negotiated by the debtor and creditor before the IDERA signed booth side and approved by the MOC.

The other obstacle of implementation relates to airlines designated for pioneer flights meaning those flights to remote areas in Indonesia. One of the airlines had the experience with the IDERA mechanism. The airline was in default and the creditor requested the deregistration for one aircraft from that airlines. Unfortunately, because of the important public purpose of the pioneer flights, the MOC did delayed on deregistration process of this aircraft for more than 5 (five) days. Based on mutual consent, the parties had to conduct the mediation process before the deregistration process. This process is not required both under the CAA of 2009 and the CTC of 2001. The Mediation process before the deregistration process is required because the pioneer flights are important for public purposes in Indonesia.

The CAA of 2009 provides the establishment of mediator. ${ }^{82}$ Such mediator shall, as authoritative mediator, have the authority making a resolution of disputes of the parties on the impact of an aircraft recommendation the MOC on aviation regulations enforcement execution of mediation between aviation service

\footnotetext{
${ }^{79}$ Based on the interview with Mrs. Enny Purnomo Widya, Partner from MKK Law-firm on 22 October 2015

${ }^{80}$ Martono K and Amad Soediro, supra note 11.

${ }^{81}$ Ambil Perma No.2 Tahun 2008

82 Ambil pasalnya $\gg>>>>>>>>>>$ 
provider, personnel and users of aviation services, settle the disputes related to aviation out-side the court, in line with Supreme Court regulation Number No. 2 Year $2008 .^{83}$ It is worthwhile to note here that, without disregards the other institution, the Director General of Civil Aviation (DGCA) or on behalf is the most proper to know related to aviation activities.

\section{XII.Conclusion}

The CAA of 2009 was an ambitious legislative attempt to adopt almost all the provisions of the CC of 1944 and implementation all of the SARP of the ICAO in one uniform national legislation. Perhaps the most successful element of the CAA of 2009 is the incorporation of elements of the CTC of 2001 and it Protocol. These successful elements have been proven by Garuda Indonesia, Lion Air, Airfast and Sriwijaya Airlines in relation to the procurements of aircraft. In the future, the role of the CAA of 2009 will be very important for the development and stimulation of Indonesia's aviation industry, as well as national economic development more generally. For the sake of legal uniformity and clarify, there is no valid reason national airlines should not comply with the CAA of 2009.

Based on number of practices, the implementation of the CTC of 2001 and its protocol is sufficient enough, in regard with the Act and Regulations, namely the CAA of 2009 and the Decree of MOC. The CAA of 2009 provides regulation on the International Interest, International Registration, Priority Rules, and Default Remedies. Those are the four elements provides in the CTC of 2001 and its Protocol, however there is an obstacles in the implementation of the CTC of 2001 and its Protocol in Indonesia such as the harmonization of the existing national laws specifically on bankruptcy and security to the regulations provides in the CTC of 2001.

The aim and objective of the CTC of 2001 is to reduce the costs of raising finance for large, high value mobile assets which routinely cross borders. The CTC of 2001 provides the financing of this type of assets whilst the accompanying protocols currently in existence - aircraft equipment. Indonesia has ratified the CTC of $2001{ }^{84}$ and for that reason the CAA of 2009 has incorporated the elements of the CTC of 2001 that regulates international interests in aircraft objects. ${ }^{85}$ This provision is purported to support aircraft procurement by the national airlines of Indonesia. ${ }^{86}$ Based on the CAA of 2009, an aircraft object may be held with international interests arising as a result of security agreements, title reservation agreements and/or leasing agreements.

The parties to an agreement may choose the law that will regulate their contractual rights and obligations. Based on the agreement between the parties, there may or may not be any link between the law chosen and a party to the agreement or the implementation of the obligations under the agreement. The parties to the agreement may also have the freedom to choose the court or jurisdiction of a State Party to the Convention or Protocol mentioned above, with or without any linkage between the chosen court and the parties or the transactions arising from the agreement. ${ }^{87}$ If the agreement is subject to Indonesian laws, the agreement must be created in an authentic form containing at least the identities of all parties, the identity of the relevant aircraft objects and the rights and obligation of the parties. ${ }^{88}$

A debtor may issue an authorization to request the annulment of the irrevocable registration and export the aircraft object to the creditor within the meaning of the Convention and Protocol for the purpose of applying for registration annulment and export of an aircraft or helicopter already displaying Indonesian registration marks and Indonesian nationality. The power of attorney for deregistration must be acknowledged and recorded by the MOC and may not be annulled without concurrence of the creditor. It will remain valid at the time the debtor declares default or if the debtor does not have the ability to pay debts. The creditor is the only party authorized to submit a request for annulment on the aircraft of helicopter registration in accordance with the terms of the request for the deregistration authorization mentioned above. ${ }^{89}$

In the case of a breach of contract by the debtor, the debtor may submit a request to the MOC, in accordance with the power of attorney for deregistration. The registration marks and nationality of the airplane

\footnotetext{
${ }^{83}$ Ambil Perma No.2 Tahun 2008

84 Convention on International Interest in Mobile Equipment, 16 November 2001, 2307 UNTS 2855, UN Doc.A/AC105/C.2/2002/CRP.3 (entered into force 1 April 2004)[Cape Town convention].

${ }^{85}$ See Presidential Decree No.7 of 2008

${ }^{86}$ Based on this provision, Indonesia airlines have bough no less than 299 aircraft from Boeing and Airbus to fulfill the country's aircraft needs.
}

${ }^{87}$ Cape Town Convention, supra note 25, art 72

${ }^{88}$ Ibid., art 73

${ }^{89}$ Civil Aviation Act, supra note 9, art 74

DOI: 10.9790/2834-1104044664 $\quad$ www.iosrjournals.org $\quad 57 \mid$ Page


or helicopter will be cancelled or annulled no later than five working days after the request is received. The MOC and other governmental agencies will have to assist with and expedite any recovery attempts contemplated by a creditor based on such an agreement. ${ }^{90}$

Some Indonesian airlines have taken advantage of the CTC of 2001 of 2001 and its Protocol, for they contain provisions which easily facilitate aircraft financing, guarantees, and securities that are useful for fleet modernization. In terms of the economic results, the CTC of 2001 has been very helpful for Indonesian airlines; between 2009 and 2013, Indonesian national airlines have procured at least 299 aircraft with the support of the CAA of 2009, which is supposed to incorporated the financing facilities provided by the CTC of 2001 and its Protocol. In the case of the above, and to assess how the CAA of 2009 has been implemented (or not) in practice, it is interesting to look at one of the most successful and profitable airlines to be establish in Indonesia in recent year.

\section{E. Montreal Convention of 1999}

The Diplomatic Conference which was held by the ICAO at Montreal on May 10 28, 1999 replaced six different legal System instruments, ${ }^{91}$ with a single legal instrument. Victims of international aircraft accidents will be better protected and compensated following the historic air law agreement embodied in the Montreal Convention concluded on May 28, 1999 among the Contracting States of ICAO at Montreal, Canada. The new instrument adopted by the Diplomatic Conference on 28 May 1999 is a separate and distinct new Montreal Convention of 1999 (MC 99), not an amendment of the Warsaw System by means of a further Protocol.

The ICAO succeeded in adopting a new regime for air carrier liability, replacing the Warsaw Convention of 1929 and five other related legal instruments with a single convention that provided for unlimited liability in relation to passengers. The MC 99 is the result of the efforts of the ICAO to reform the Warsaw Convention of 1929 through wholesale amendment rather than inter-carrier agreement. ${ }^{92}$ The stated goals of the MC 99 were the need to modernize and consolidate the Warsaw Convention of 1929 and related instruments and recognition that collective State action for further harmonization and codification of certain rules governing international carriage by air through a new Convention was the most adequate means of achieving an equitable balance of interests.

The MC 99 is basically the consolidation of the original Warsaw Convention of 1929 and the subsequent protocols, namely, the Hague Protocol of 1955, the Montreal Protocol Nos. 3 and 4 of 1975, the Guatemala City Protocol of 1971, and the Guadalajara Supplementary Convention of 1961. Victims of international air accidents will be better protected and compensated as a result of the historic air law agreement adopted by among the Contracting State's delegates of ICAO. From 11 to 28 May 1999 the ICAO headquarters at Montreal hosted a Diplomatic Conference convened to consider, with a view to adoption, a Draft Convention intended to modernize and replace the instruments of the Warsaw system. Some 525 participants from 121 Contracting States of ICAO attended, ${ }^{93}$ one non-contracting State, 11 observer delegations from international organizations, a total of 544 registered participants took part in the historic three-week conference which began on 10 May.

\footnotetext{
${ }^{90}$ Ibid., arts $75-76$ Steven Dempsey. ,Ed. (2005), XXX- Part I, Ann. Air \& Sp. L.

${ }^{92}$ Prof. Dr. Doo Hwan Kim

${ }^{93}$ ) While this is a very impressive attendance, it represents only $65.4 \%$-less than two-thirdsof the total ICAO membership which now stands at 185 .
}

${ }^{91}$ Protocol to Amend the Convention for the Unification of Certain Rules Relating to International Carriage by Air, signed at Warsaw on 12 October 1929, done at Warsaw on 28 September 1955; Protocol to Amend the Convention for the Unification of Certain Rules Relating to International Carriage by Air, signed at Warsaw on 12 October 1929, as Amended by the Protocol done at The Hague on 28 September 1955, signed at Guatemala City, on 8 March 1971; Additional Protocol No.1 to Amend the Convention for the Unification of Certain Rules Relating to International Carriage by Air, signed at Warsaw on 12 October 1929, signed at Montreal on 25 September 1975; Additional Protocol No.2 to Amend the Convention for the Unification of Certain Rules Relating to International Carriage by Air, signed at Warsaw on 12 October 1929, as Amended by the Protocol done at The Hague on 28 September 1955, signed at Montreal on 25 September 1975; Additional Protocol No.3 to Amend the Convention for the Unification of Certain Rules Relating to International Carriage by Air, signed at Warsaw on 12 October 1929, as Amended by the Protocol done at The Hague on 2 September 1955, and at Guatemala City on 25 September 1971; Additional Protocol No.4 to Amend the Convention for the Unification of Certain Rules Relating to International Carriage by Air, signed at Warsaw on 12 October 1929, as Amended by Protocol done at The Hague on 28 September 1955, signed at Montreal on 25 September 1975, see Paul 
The Montreal Conference was a success since it adopted a new Convention for the Unification of Certain Rules for International Carriage by Air. The new Montreal Convention adopted by the diplomatic conference entered into force as soon as it had been ratified by 30 States. Fifty-two States including USA, China, EU etc. signed the new Montreal Convention at the conclusion of the historic diplomatic conference. This Montreal Convention entered into force on November 4, 2003. At present, 108 countries including the United States, the United Kingdom, Canada, France, Germany, Korea, Japan, Italy, China, Sweden, Brazil, Spain etc. are affiliated with the MC $99 .{ }^{94}$

\section{Scope of Application}

The MC 99 applies to carriage of persons, baggage or cargo performed by aircraft for reward in which, according to the agreement between the parties, the place of departure and the place of destination, whether or not there be a break in the carriage or a transshipment, are situated either within the territories of two State Parties, or within the territory of a single State Party if there is an agreed stopping place within the territory of another State, even if that State is not a State Party. Carriage between two points within the territory of a single State Party without an agreed stopping place within the territory of another State is not international carriage for the purposes of the Montreal Convention of 1999. It applies equally to gratuitous carriage by aircraft performed by an air transport undertaking.

Carriage to be performed by several successive carriers is deemed, for the purposes of MC 99 , to be one undivided carriage if it has been regarded by the parties as a single operation, whether it had been agreed upon under form of a single contract or of a series of contracts, and it does no lose its international character entirely because one contract or a series of contracts is to be performed entirely within the territory of the same State. The MC 99 applies also to combine carriage subject to the terms contained therein'

\section{Compensation}

The carrier is liable for damage sustained in case of death or bodily injury of passengers upon condition only that the accident which caused the death or injury took place on board the aircraft or in the course of any of the operations of embarking or disembarking. In case of death or injury of passengers, the compensation will not exceed 100,000 Special Drawing Rights (SDR) for each passenger, and the carrier cannot exclude or limit its liability.

The carrier is not be liable for damages in case of death or injury of passengers, to the extent that they exceed for each passenger 100,000 (SDR) if the carrier proves that (a) such damage was not due to the negligence or other wrongful act or omission of the carrier or its servants or agents; (b) such damage was solely due to the negligence or other wrongful act or omission of a third party. With regard to the Air Asia QZ8501 crash, the compensation does not apply taking into account that Indonesia has not ratified the MC 99.

\section{Advance Payment}

In accordance with Article 38 of the MC 99, that in the case of aircraft accidents resulting in a passenger's injury or death, if required by its national law, the air carrier shall provide advance payments without delay in order to assist entitled persons in meeting immediate economic needs. The amounts paid will be deductible from the final settlement and do not constitute a recognition of liability. In relation to this provision, the Conference also adopted a Resolution that encouraged States to take appropriate measures, under their respective national law, to promote such action by carriers. ${ }^{95}$

\section{Insurance Liability}

A mandatory insurance requirement is set forth at Article 50 of the MC 99. At the core of this provision is the right of any State Party to request, from an air carrier operating into that State, to furnish evidence to the effect that adequate insurance coverage is maintained by the carrier. Proposed by the ICAO Legal Bureau and supported by the study group and later by the SGMW, a mandatory insurance clause had become, at least in principle, a matter of consensus during the preparatory stages of the MC 99. It is expected that the heightened degree of vigilance resulting from this clause and the involvement of the insurance sector will have a positive effect for the overall safety or air transport operations. ${ }^{96}$

\footnotetext{
${ }^{94}$ ) http://www.icao.int/secretariat/legal/List\%20of\%20Parties/Mt199_EN.pdf

${ }^{95}$ Ludwig Weber and A. Jakob, The Modernization of the Warsaw System : The Montreal Convention of 1999, in Milde M.Ed., (1999), XXIV, Ann. Air \& Sp. L., at 343.

${ }^{96}$ Ibid., at 345 


\section{Jurisdiction}

With regard to jurisdiction, an action for damages must be brought, at the option of the plaintiff, in the territory of one of the State Parties, either

(a) before the court of the domicile of the carrier; or

(b) before the court of its principal place of business, or

(c) before the court where it has a place of business through which the contract was made; or

(d) before the court at the place of destination.

In addition, in respect of damage resulting from the death or injury of a passenger, an action may be brought in the territory of a State Party in which at the time of the accident the passenger had his or her principal and permanent residence and or from which the carrier operates services for the carriage of passengers by air, either on its own aircraft or another carrier's aircraft pursuant to a commercial agreement, and in which that carrier conducts its business of carriage of passengers by air from premises leased or owned by the carrier itself or by another carrier with which it has a commercial agreement. In this regard "commercial agreement" means an agreement, other than an agency agreement, made between carriers and relating to the provision of their joint services for carriage of passengers by air, whilst "principal and permanent residence" means the one fixed and permanent abode of the passenger shall not be the determining factor in this regard. In relation to Air Asia QZ8501 the fifth jurisdiction does not apply because Indonesia has not yet ratified Montreal Convention of 1999.

\section{Ratification of Montreal Convention of $\mathbf{1 9 9 9}$}

With regard to ratification of the MC 99, basically, after Focus Group Discussion (FGD) which participated by Prof. L. Weber (Legal Adviser of the DGAC) in Solo, Central Java, on 5 October 2015 Indonesia intends to ratify the MC 99. This focus discussion participated from airlines, Indonesian National Air Carriers Association (INACA), International Air Transport Association (IATA), Supreme Court, Law and Human Rights Ministry, Foreign Affairs Ministry, the DGAC and other stakeholders related to aviation activities. Actually, for the purpose of ratification has been prepared legal drafting to fulfill the formalities file to the Parliament of the Republic of Indonesia (ROI). The intension to ratify the MC 99 in line with the General Assembly Res.A-38-19 which urges all States that have not done so to become Parties to the Montreal Convention of 1999 as soon as possible. ${ }^{97}$

\section{F. Contribution to the ASEAN Countries}

\section{ASEAN Cooperation on Aircraft Search and Rescue}

The Government of the ROI, Malaysia, the Republic of the Philippines, the Republic of Singapore and the Kingdom of Thailand (hereinafter referred to as-ASEAN) have signed an Agreement for the Facilitation of Search for Aircraft in Distress and Rescue of Survivors of Aircraft Accidents, at Singapore on 14 April 1972, but it not yet comes into force due to lack of ratification of the signatory States. This agreement consist of seven Articles such as follows:

The agreement provides that the contracting parties to undertake to provide such measures of assistance as may be necessitated by the circumstances to aircraft in distress in their territories and neighboring sea as they find practicable. In assistance to aircraft in distress and to survivors of aircraft accident, shall do so regardless of the nationality of such aircraft or survivors. In addition to that, a party shall, subject to the control of its own authorities, permit immediate entry of aircraft, vessels, equipment and personnel necessary to search for aircraft in distress, or rescue survivors of aircraft accidents, into any areas other than prohibited areas in which it is believed that such aircraft or survivors are located.

Each contracting parties shall publish, in their respective Aeronautical Information Publications (AIP), all necessary information concerning such authorities and the measures of control exercised by them. Subject to the control of their own authorities, the parties shall make arrangements to ensure entry without delay into their territories on a temporary basis of qualified personnel required for search and rescue in connection with aircraft in distress. They shall facilitate the temporary entry into their territories of all aircraft, vessels and equipment required for search and rescue and shall admit these item free from customs duties and other taxes or charges and the application of regulations of any nature restricting the importation of goods and the subsequent reexportation thereof.

The competent authorities of a Contracting Parties which wishes its search and rescue units to enter the territory of another Contracting Parties of search and rescue purposes shall transmit a request, giving full details of the projected mission and the necessity therefore, to the Rescue Co-ordination Center (RCC) of the Contracting Party concerned or to such other authority as has been designated by the Contracting Party for that

\footnotetext{
${ }^{97}$ See General Assembly Res.A38-20 regarding Promotion of the Montreal Convention of 1999

DOI: $10.9790 / 2834-1104044664 \quad$ www.iosrjournals.org $60 \mid$ Page
}


purpose. This request shall, when appropriate, be made through the medium of a flight plan (or similar message in the case of a rescue vessels or boat),

The ASEAN Agreement is subject to ratification by the signatory Governments. The instrument of ratification shall be deposited with Ministry of Foreign Affairs of Singapore. The agreement is open for accession by a new member of ASEAN countries. The instruments of accession shall be deposited with the Ministry of Foreign Affairs of Singapore as well. In addition to that, the Agreement also provides denunciation of the member's parties. It provide that a contracting parties may at any time give formal notice of its intention to withdraw from the Agreement and such withdrawal shall take effect one year from the date of the notification to the Ministry of Foreign Affairs of Singapore, which shall immediately notify all the other Contracting Parties.

To enhance cooperation within ASEAN Countries, it is necessary to call for establishment of ASEAN Countries search and rescue forum to promote cooperation in aircraft safety and search and rescue (SAR) through activities such as aeronautical Information Publication (AIP) sharing, technological cooperation and exchange of visits of authorities concerned.

In addition to that, enhancing cooperation could be the use of facilities in each other's Search and Rescue Regions (SRR) while engaged in search and rescue mission, existing information flow and information during search and rescue operations, cooperation in the management of persons rescued or missing at airspace, conduct frequent regional search and rescue exercise to ensure the efficiency and effectiveness of the search and rescue communications and cooperative arrangements.

To enhance cooperation within ASEAN Countries, it is easier when there is a common legal frame work as legal ground, considering that all ASEAN countries are parties to the Chicago Convention of 1944. It is strongly suggested that Multilateral Agreement for the Facilitation of Search and Rescue for Aircraft in Distress and Rescue of Survivors of Aircraft Accidents signed at Singapore on 14 April 1972 shall be revised to cope the ASEAN Countries.

ASEAN Countries should consider drafting a new ASEAN Multilateral Agreement on Aircraft Search and Rescue right away. In the meantime, ASEAN Governments should take measures to enhance their cooperation, including the use of each other's facilities in rescue missions, common standard operating procedures for entry into the territorial air space and exchange of information, arrangement in undefined boundary areas, more search and rescue training program and more search and rescue exercises.

\section{ASEAN Multilateral Agreement on Commercial of Non-Scheduled Air Services}

Like European countries, ASEAN countries also created a Multilateral Agreement on Commercial Rights of Non-Scheduled Air Services Among ASEAN (MACRNAS-ASEAN), done at Manila, the Philippines on 30 March 1971, signed by the Governments of the Republic of Indonesia, Malaysia, the Philippines, Singapore and Thailand. ${ }^{98}$ The purpose of this agreement is to accelerate and intensify the implementation of the aims and purposes of ASEAN as embodied in the ASEAN Declaration.

Article 2 (MACRNAS-ASEAN) concerns the exchange of third and fourth freedom of the air. The member States of ASEAN agree to admit aircraft registered in ASEAN States and operated by a national of one of the member states or a firm or corporation substantially owned and effective controlled by a national of one of the member States, duly authorized by the competent aeronautical authority of the State and engaged in nonscheduled international flights for pay for hire in the territories within the ASEAN region, freely to their respective territories for the purpose of third and fourth freedom traffic in respect of the airports contained in the Annex of the agreement without the imposition of the regulations, conditions or limitations provided for in paragraph 2, Article 5 of the 1944 Chicago convention, except for traffic control where such aircraft are engaged in:

a. flights for the purpose of meeting emergency or humanitarian needs;

b. taxi-class passenger flights of occasional character on request, provided that on each flight the aircraft does not carry more than 8 passengers and provided that the destination is chosen by the hirer or hirers and no part of the capacity of the aircraft is resold to the public;

c. flights on which the entire space is hired by a single individual, firm, corporation or institution for the carriage of his/her or its personnel or merchandise provided that on each flight no part of such space is resold and the total freight does not exceed 40 passengers and total freight does not exceed 2 tones and provided the total frequency between any two Member States does not exceed 2 flights per week;

d. flights on which the entire space is hired for the transport of freight exclusively, provided that on each flight the total freight does not exceed 4 tones. ${ }^{99}$

\footnotetext{
${ }^{98}$ I. A. Vlasic and MA Bradley, supra at $30-34$

${ }^{99}$ See Multilateral Agreement on Commercial Rights of Non-Scheduled Air Service Among the ASEAN, done at Manila, on 30 March 1971, reprinted in I. A. Vlasic and M. A. Bradley, the Public International Law of Air Transport : Material and Documents. Montreal : Institute of Air and Space Law, Mc Gill University, 1974, pages 30-34.
} 


\section{ASEAN Multilateral Agreement of Air Services}

The member States of the ASEAN, ${ }^{100}$ on 20 May 2009, signed ASEAN Multilateral Agreement on Air Services (AMAAS) ${ }^{101}$ at Manila, the Philippines. ${ }^{102}$ The purpose of AMAAS is to implement the Declaration of ASEAN Concord II issued in Bali, Indonesia on 7 October 2003, in which ASEAN committed itself to deepen and broaden its internal economic integration and linkages with the world economy to realize an ASEAN Economic Community. It intends to accelerate the open sky arrangements and advancing liberalization in air services, with provides strategic actions to further liberalize air services in ASEAN; to promote an enabling environment for a single and unified aviation market in ASEAN; to ensure the highest degree of safety and security in international air transport and reaffirm grave concern about acts or threats against the security of aircraft, which jeopardize the safety of persons or property, adversely affect the operation of air transportation, and undermine public confidence in the safety of civil aviation.

The ultimate goal of AMAAS is the full liberalization of the aviation market without any limitation on, among others, destinations, frequencies, capacity, the applicable tariff or freedoms of the air; "unlimited air transportation rights" are to be implemented "in stages" in accordance with the preparedness of national airline companies for competition. ${ }^{103}$ In this regard, the Republic of Indonesia has made it its goal to conclude multilateral air agreements based on the national interest and principles of fairness and reciprocity. It is of interest to examine ASEAN multilateral Agreements on Air Services that Indonesia has signed with ASEAN Countries to understand the nature of the Indonesian aviation market to date.

The AMAAS provides preamble, definition such as convention, aeronautical authorities, territory of states, airline, air service, tariffs, route, $2^{\text {nd }}$ freedom of the air, user charges; the body of agreement consist of grant of rights, designation and authorization of airlines, revocation, suspension and limitation of authorization, aviation safety, aviation security, tariff, commercial activities, non-discrimination treatment, customs duties; miscellaneous provisions consist of application of laws and regulations, entry into force, ratification, the duration of agreements, consultations, settlement of dispute provisions, registration and conclusion.

Most importantly, and also the focus of this article, is the matter of how routes, frequencies, capacity, tariff and ownership and effective control provisions in the past compare to more liberal multilateral or bilateral air agreements and other provisions of the present. After the initial signing of the AMAAS in May 2009, ${ }^{104}$ Indonesia proceeded to ratify in April 2014 Protocols 5 and 6 to the AMAAS, which respectively govern unlimited third and fourth freedom and unlimited fifth freedom traffic rights between ASEAN capital cities. ${ }^{105}$ Indonesia's own Civil Aviation Act also contains provisions allowing the signing of open skies agreement with foreign countries.

\section{The ASEAN Aviation Training and Education Summit}

The ASEAN Aviation training and education conducted in Jakarta from 22-23 January 2013. The meeting was participated by the DGAC of Indonesia, the President of the European Civil Aviation Conference $($ ECAC), the Director Generals and other high-ranking officials of ASEAN member States. In this event, ICAO Secretary general Raymond Benjamin was the keynote speaker. The main objective of the meeting is the development of a framework for closer cooperation between ASEAN countries to maximize the use of existing resources in the field of aviation training and education.

100 The Governments of Brunei Darussalam, the Kingdom of Cambodia, the Republic of Indonesia, the Lao People's Democratic Republic (hereinafter referred as "Lao PDR"), Malaysia, the Union of Myanmar, the Republic of the Philippines, the Republic of Singapore, the Kingdom of Thailand and the Socialist Republic of Viet Nam, [the Member States of ASEAN]

101 ASEAN Multilateral Agreement on Air Services, 20 May 2009, online: ASEAN <http://www.asean.org/22628.htm>.

102 Amad Sudiro and K.Martono, Indonesia's Aviation Law in the Framework of the ASEAN Multilateral Air Agreements, submitted to the Celebrating 70 Years of the Chicago Convention and 100 Years of World Commercial Aviation Forum, on December 17-19 December 2014, hosted by Northwest University of Political Science \& Law, China, Mc Gill University, Institute of Air and Space Law, Organized by the Institute of Air and Space Law, NWUPL School of International Law , NWUPL, [ Amad Sudiro \& K.Martono, AMAAS]

${ }^{103}$ Indonesia, Act concerning Civil Aviation, Act No 1 of 2009 [Civil Aviation Act], Ministry of Transportation Republic of Indonesia, online: Directorate General of Civil Aviation 〈http://hubud.dephub.go.id/?en/uu>, art 86(3).

${ }^{104}$ ASEAN Multilateral Agreement on Air Services, 20 May 2009, online: ASEAN く>.

${ }^{105}$ Protocol 5 on Unlimited Third and Fourth Freedom Traffic Rights between ASEAN Capital Cities and Protocol 6 on Unlimited Fifth Freedom Traffic Rights between ASEAN Capital Cities, see online: ASEAN < >. 
The event should be seen against the background of the ASEAN "Roadmap for the integration of the travel sector" and the region's vision of a single ASEAN air transport market as of 2015. As a part of the ASEAN Aviation Training and Education Summit, Mr Raymond Benjamin also had the opportunity to visit Indonesia Civil Aviation Institute (ICAI), which is the main governmental training institution in the field of civil aviation in Indonesia, as well as the Maintenance Facility and the Training Center of Garuda Indonesia Airlines. ${ }^{106}$

\section{Conclusion}

Based on the above-mentioned, could be concluded that Indonesia as a member of the ICAO complies with the standard and recommended practices (SARP) and active to support and collaborate with other institution in the international and regional level.

\section{National Laws and Regulations}

Bibliography

[1] Act Concerning Civil Aviation, Act no.1 of 2009. State Gazette of the Republic of Indonesia Number 1 of 2009, Supplement State Gazette of the ROI Number 4956. online: Directorate General of Civil Aviation http://hubud.dephub.go.id/?en/uu

[2] Ministerial Decree Concerning Aircraft Registration. Ministerial Decree No.KM 49 of 2009 ( 10 June 2009)

\section{International Air Law}

[3] Convention on International Civil Aviation, signed at Chicago on 7 December 1944

[4] Convention on Offences and Certain Other Acts Committed on Board Aircraft, signed at Tokyo 1963

[5] Convention for the Suppression of Unlawful Seizure of Aircraft, signed at the Hague on 16 December 1970

[6] Convention for the Suppression of Unlawful Acts Against the Safety of Civil Aviation, signed at Montreal on 23 September 1971

[7] Convention on International Interest in Mobile Equipment, 16 November 2001, 2307 UNTS 2855, UN Doc. A/AC105/C.2/2002/CRP.3 (entered into force 1 April 2004)

[8] Convention on International Interest in Mobile Equipment, 16 November 2001, 2307 UNTS 2855

\section{Protocol}

[9] Protocol to the Convention on Interest Mobile Equipment on Matters Specific to Aircraft Equipment, 16 November 2001 (entered into force 1 March 2006).

[10] Protocol to the Convention on Interest Mobile Equipment on Matters Specific to Aircraft Equipment, 16 November 2001 (entered into force 1 March 2006).

[11] Protocol to Amend the Convention for the Unification of Certain Rules Relating to International Carriage by Air, signed at Warsaw on 12 October 1929, done at Warsaw on 28 September 1955 ;

[12] Protocol to Amend the Convention for the Unification of Certain Rules Relating to International Carriage by Air, signed at Warsaw on 12 October 1929, as Amended by the Protocol done at The Hague on 28 September 1955, signed at Guatemala City, on 8 March 1971 ;

[13] Additional Protocol No.1 to Amend the Convention for the Unification of Certain Rules Relating to International Carriage by Air, signed at Warsaw on 12 October 1929, signed at Montreal on 25 September 1975;

[14] Additional Protocol No.2 to Amend the Convention for the Unification of Certain Rules Relating to International Carriage by Air, signed at Warsaw on 12 October 1929, as Amended by the Protocol done at The Hague on 28 September 1955, signed at Montreal on 25 September 1975

[15] Additional Protocol No.3 to Amend the Convention for the Unification of Certain Rules Relating to International Carriage by Air, signed at Warsaw on 12 October 1929, as Amended by the Protocol done at The Hague on 2 September 1955,

[16] Guatemala City on 25 September 1971;

[17] Additional Protocol No.4 to Amend the Convention for the Unification of Certain Rules Relating to International Carriage by Air, signed at Warsaw on 12 October 1929, as Amended by Protocol done at The Hague on 28 September 1955, signed at Montreal on 25 September 1975

[18] Protocol 5 on Unlimited Third and Fourth Freedom Traffic Rights between ASEAN Capital Cities and Protocol 6 on Unlimited Fifth Freedom Traffic Rights between ASEAN Capital Cities, see online: ASEAN $<>$.

[19] Books

[20] Milde M.Ed., Annals of Air and Space Law, Vol.XXIV-1999. Toronto : The Carswell Company Ltd.

[21] Paul Stephen Dempsey Ed., Annals of Air and Space Law, 2005 Volume XXX-Part I. Toronto : The Carswell Company Ltd

Articles

[22] Amad Sudiro and K.Martono, Indonesia's Aviation Law in the Framework of the ASEAN Multilateral Air Agreements, submitted to the Celebrating 70 Years of the Chicago Convention and 100 Years of World Commercial Aviation Forum, on December 17-19 December 2014, hosted by Northwest University of Political Science \& Law, China, Mc Gill University, Institute of Air and Space Law, Organized by the Institute of Air and Space Law, NWUPL School of International Law , NWUPL,

I. A. Vlasic and M. A. Bradley, the Public International Law of Air Transport : Material and Documents. Montreal : Institute of Air and Space Law, Mc Gill University, 1974.

[23] Ludwig Weber and A. Jakob, The Modernization of the Warsaw System : The Montreal Convention of 1999, in Milde M.Ed., Annals of Air and Space Law, Vol.XXIV-1999. Toronto : The Carswell Company Ltd, p.343

[24] Martono and Amad Sudiro, Current Air Transport Regulations I n Indonesia, published in Volume XXXVIII Annals of Air and Space Law 55-9 (2013)

[25] Mieke Komar Kantaatmadja, The 2001 Cape Town Convention on International Interest in Mobile Equipment/the Aviation Protocol and Relevant Issues in Indonesian Aviation Law. Volume 8, Number 4 July 2011,p.633

\footnotetext{
${ }^{106}$ ICAO News Brief see Website : www.icao.int
} 
[26] Muzaffar Ismail on behalf of Santosa Eddy Wibowo, Indonesia Civil Aviation Growth and Technical Cooperation, Submitted to the Global Aviation Cooperation Symposium, ICAO Head Quarters, Montreal, 30 Sept-3 October 2014.

Documents

[27] UN Doc. A/AC105/C.2/2002/CRP.3 (entered into force 1 April 2004)[Cape Town convention].

[28] The $38^{\text {th }}$ General Assembly Resolution, Montreal, 24 September -4 October 2013 A38-4.

[29] General Assembly Res.A38-20 regarding Promotion of the Montreal Convention of 1999.

[30] Multilateral Agreement on Commercial Rights of Non-Scheduled Air Service Among the ASEAN, done at Manila, on 30 March 1971.

[31] ASEAN Multilateral Agreement on Air Services, 20 May 2009, online: ASEAN

<http://www.asean.org/22628.htm>.

Others

[32] Regulation Impact Statement "Implementation of the Cape Town Convention, paper unpublished.

[33] Indonesia's Civil Aviation Development, A paper submitted to Sixth Meeting of Worldwide Air Transport Conference, Montreal, 18 to 22 March 2013.

[34] The interview with Ms. Enny Purnomo Widya, Partner from MKK Lawfirm on 22 October 2015

[35] ICAO News Brief see Website : www.icao.int 